Article

\title{
Enhanced Enzymatic Hydrolysis of Pennisetum alopecuroides by Dilute Acid, Alkaline and Ferric Chloride Pretreatments
}

\author{
Shangyuan Tang ${ }^{1, \dagger}$, Chunming $X u^{2,+}$, Linh Tran Khanh $V u^{3}{ }^{\circledR}$, Sicheng Liu ${ }^{1}$, Peng $Y e^{1}$, \\ Lingci Li ${ }^{1}$, Yuxuan $\mathrm{Wu}^{1}{ }^{1}$, Mengyu Chen ${ }^{1}$, Yao Xiao ${ }^{1}$, Yue Wu ${ }^{1}$, Yining Wang ${ }^{1}$, Qiong Yan ${ }^{1, *}$ \\ and Xiyu Cheng $1, *$ (1) \\ 1 College of Life Sciences and Bioengineering, School of Science, Beijing Jiaotong University, Beijing 100044, \\ China; 16121638@bjtu.edu.cn (S.T.); 16292010@bjtu.edu.cn (S.L.); 17121611@bjtu.edu.cn (P.Y.); \\ 18121614@bjtu.edu.cn (L.L.); 15272020@bjtu.edu.cn (Y.W.); 18272032@bjtu.edu.cn (M.C.); \\ 17271250@bjtu.edu.cn (Y.X.); 18272052@bjtu.edu.cn (Y.W.); 17272018@bjtu.edu.cn (Y.W.) \\ 2 Key Laboratory of Cleaner Production and Integrated Resource Utilization of China National Light Industry, \\ Beijing Technology and Business University, Beijing 100048, China; xucm@th.btbu.edu.cn \\ 3 Faculty of Chemical and Food Technology, Ho Chi Minh City University of Technology and Education, \\ No. 1 Vo Van Ngan Street, Linh Chieu Ward, Thu Duc District, Ho Chi Minh City 71307, Viet Nam; \\ linhvtk@hcmute.edu.vn \\ * Correspondence: qyan@bjtu.edu.cn (Q.Y.); xycheng@bjtu.edu.cn (X.C.); Tel.: +86-10-51684351-209 (X.C.) \\ + These authors contributed equally.
}

Academic Editor: Ivet Ferrer

Received: 8 April 2019; Accepted: 30 April 2019; Published: 2 May 2019

\begin{abstract}
In this study, effects of different pretreatment methods on the enzymatic digestibility of Pennisetum alopecuroides, a ubiquitous wild grass in China, were investigated to evaluate its potential as a feedstock for biofuel production. The stalk samples were separately pretreated with $\mathrm{H}_{2} \mathrm{SO}_{4}, \mathrm{NaOH}$ and $\mathrm{FeCl}_{3}$ solutions of different concentrations at $120^{\circ} \mathrm{C}$ for $30 \mathrm{~min}$, after which enzymatic hydrolysis was conducted to measure the digestibility of pretreated samples. Results demonstrated that different pretreatments were effective at removing hemicellulose, among which ferric chloride pretreatment (FCP) gave the highest soluble sugar recovery $(200.2 \mathrm{mg} / \mathrm{g}$ raw stalk) from the pretreatment stage. In comparison with FCP and dilute acid pretreatment (DAP), dilute alkaline pretreatment (DALP) induced much higher delignification and stronger morphological changes of the biomass, making it more accessible to hydrolysis enzymes. As a result, DALP using 1.2\% NaOH showed the highest total soluble sugar yield through the whole process from pretreatment to enzymatic hydrolysis $(508.5 \mathrm{mg} / \mathrm{g}$ raw stalk). The present work indicates that DALP and FCP have the potential to enhance the effective bioconversion of lignocellulosic biomass like $P$. alopecuroides, hence making this material a valuable and promising energy plant.
\end{abstract}

Keywords: Pennisetum alopecuroides; dilute alkaline pretreatment; ferric chloride pretreatment; enzymatic hydrolysis

\section{Introduction}

With the growth of vehicles and an over-reliance on fossil fuels in industrial development, biofuel production from non-food crop feedstocks (e.g. agricultural residues, forest residues and industrial wastes) has drawn considerable attention [1-8]. In China, anaerobic digestion of organic wastes has been successfully used for biogas production both domestically, as well as at a larger scale [2-6]. Different biomass substrates, such as cornstalk, rice straw, wheat straw and pine foliage, have also been investigated for the production of bioethanol [9-12]. In addition to these lignocellulosic biomass wastes, 
Pennisetum alopecuroides is a potential prolific renewable herbaceous plant that is widely distributed in many provinces of China. Some Pennisetum species are cultivated as an important feedstock for the animal feed industry in north China, northeast China, southwest China and the middle-lower Yangtze Plain [8]. The annual dry matter yield of Pennisetum grass ranges from 40 to $50.2 \mathrm{t} / \mathrm{ha}$, which is much higher than the yields of sugarcane and corn (13 21 t/ha) and comparable to that of miscanthus (27 38 t/ha) [9,10]. While Miscanthus species and some other energy plant candidates (e.g., switchgrass) have attracted widespread interest in the bio-energy field, studies on P. alopecuroides have been relatively limited. Given its rapid growth, high yield, high adaptability, low cost and environmentally benign production, $P$, alopecuroides was selected as a substrate in the current study to evaluate its application prospects in biofuel production.

The recalcitrant structure of lignocellulosic biomass is the main constraint of its bioconversion [13-18]. Varied pretreatment strategies such as chemical methods (e.g., acid, bases, salts and solvents), physico-chemical processes (e.g., steam explosion, liquid hot water (LHW) and ammonia fiber expansion (AFEX) and biological methods have been developed in attempts to remove hemicellulose and/or lignin from lignocellulosic wastes and reduce the crystallinity of cellulose [13,19-24]. It is widely accepted that efficient pretreatment should avoid the use of expensive chemicals, improve fiber reactivity and maximize the recovery/formation of fermentable sugars, avoid formation of enzyme inhibitory byproducts, preserve cellulose and hemicellulose fractions that are easily accessible to hydrolysis enzymes and minimize energy requirements [11-14]. However, no single strategy could efficiently meet all these criteria due to the variations in material characteristics. The chemical pretreatment of lignocellulosic materials has been widely employed in many pilot and large-scale cellulosic ethanol plants because it is ideal for low-lignin materials and has high reactivity at mild conditions [12-14]. A chemical method is hence a suitable pretreatment strategy for P. alopecuroides, a low-lignin material.

Among several chemical methods, dilute acid pretreatment is most commonly used, due to its advantages in cost and process severity [13,14]. One major limitation of acid pretreatment is its requirement of corrosion-resistant reactors [13]. On the other hand, corrosion problems and sugar degradation are less severe in alkaline processes than in acid pretreatment. Alkaline pretreatment is also effective in delignifying the biomass $[7,20,22,24]$. A mild alkali concentration $(<4 \% w / w)$ favors enzymatic hydrolysis especially for low-lignin materials $[13,14]$. Previous studies also showed that pretreatment of lignocellulosic biomass using Lewis acids such as $\mathrm{FeCl}_{3}$ enhances digestibility of biomass, producing reusable solubilized hemicellulose [25-27]. Operating at milder temperature conditions $\left(120^{\circ} \mathrm{C}\right.$ vs $160 \sim 260^{\circ} \mathrm{C}$ in steam explosion and LHW pretreatments) in the current study means that dilute acid pretreatment (DAP), dilute alkaline pretreatment (DALP) and ferric chloride pretreatment (FCP) reduce energy consumption and the formation of enzyme inhibitory byproducts [11]. Up to date, DAP, DALP and FCP have been used on a wide range of low-lignin biomasses ranging from wood (cedar, pine, hemlock) to agricultural residues (corn stover, wheat and barley straw, switchgrass, Miscanthus) [18-24]. To our best knowledge, the effects of these methods on the biodigestibility of P. alopecuroides has not been systematically studied to identify the ideal pretreatment process or to evaluate the potential of $P$. alopecuroides biomass in the bioconversion industry. Moreover, some previous studies have also shown that effective removal of lignin and/or hemicellulose in acid/alkaline pretreatments did not result in a significant increase in reducing sugar yields (only 91.4-92 mg/g) [19,21]. These results indicate that the exact roles of different pretreatments in the improvement of hydrolysis efficiency were complicated, thereby necessitating further research to better understand the mechanism.

In the present study, three chemical pretreatments including DAP, DALP and FCP were systematically investigated to develop an efficient pretreatment strategy for enhancing enzymatic hydrolysis of $P$. alopecuroides biomass. The composition and microstructure of substrates in response to these pretreatments were investigated to better understand the exact roles of each pretreatment in changing biomass recalcitrance and subsequent enzymatic hydrolysis enhancement. The fermentable sugar production from the pretreated P. alopecuroides biomass was also studied to evaluate its application prospects for biofuel production. 


\section{Results and Discussion}

\subsection{Effect of Different Pretreatments on Biomass Composition}

The pretreatment process decreases the recalcitrance of lignocellulosic substrates by removing lignin and hemicellulose components, thereby exposing cellulose to the hydrolysis enzyme [28,29]. The P. alopecuroides samples were subjected to different pretreatments, including DAP, DALP and FCP. The solid yield and compositional change of the stalk samples are important indices to evaluate the effectiveness of their pretreatments. As shown in Table 1, the dry matter retained after different pretreatments was about $53.3-58.2 \%$. A P. alopecuroides sample pretreated by DALP had a higher solid yield as compared with those pretreated with DAP and FCP. The weight loss of P. alopecuroides biomass could be attributed to the solubilization of its components into the aqueous solution. The higher solid yield (or lower weight loss) indicate that less lignocellulosic components were converted into soluble substances. In comparison to DALP, DAP and FCP thereby gave higher soluble sugar concentrations ( $86.7 \mathrm{mg} / \mathrm{g}$ raw stalk (RS) vs $112.2 \mathrm{mg} / \mathrm{g}$ RS and $193.4 \mathrm{mg} / \mathrm{g}$ RS, respectively).

Table 1. Effect of DAP/DALP/FCP of Pennisetum alopecuroides biomass on its chemical composition.

\begin{tabular}{cccccc}
\hline $\begin{array}{c}\text { Different } \\
\text { Pretreatment }\end{array}$ & $\begin{array}{c}\text { Solid } \\
\text { Yield (\%) }\end{array}$ & $\begin{array}{c}\text { Hemicellulose } \\
\text { Content (\%) }\end{array}$ & $\begin{array}{c}\text { Cellulose } \\
\text { Content (\%) }\end{array}$ & $\begin{array}{c}\text { Lignin } \\
\text { Content (\%) }\end{array}$ & $\begin{array}{c}\text { Soluble Sugar } \\
\text { from Pretreatment } \\
\text { (mg/g RS) }\end{array}$ \\
\hline Control & - & $28.7 \pm 0.4$ & $41.8 \pm 0.9$ & $17.5 \pm 0.6$ & $20.0 \pm 0.4$ \\
$\mathrm{DAP}, 3 \% \mathrm{H}_{2} \mathrm{SO}_{4}$ & $53.3 \pm 1.7$ & $15.0 \pm 1.7$ & $55.9 \pm 2.3$ & $17.1 \pm 1.5$ & $112.2 \pm 2.0$ \\
$\mathrm{DALP}, 1.0 \% \mathrm{NaOH}$ & $58.2 \pm 1.2$ & $15.3 \pm 0.1$ & $64.1 \pm 1.7$ & $11.7 \pm 0.6$ & $86.7 \pm 0.2$ \\
$\mathrm{FCP}, 3.2 \% \mathrm{FeCl}_{3}$ & $55.9 \pm 1.8$ & $11.9 \pm 1.3$ & $60.8 \pm 1.3$ & $16.4 \pm 0.7$ & $193.4 \pm 8.7$ \\
\hline
\end{tabular}

${ }^{1}$ The soluble sugar yield in the pretreatment process was calculated based on per g raw stalk (RS). Values are means of triplicate \pm standard deviation.

Compositional analysis showed that the weight loss of the stalk samples was mainly due to hemicellulose hydrolysis by both DAP and FCP (Table 1). A previous study also reported that soluble sugars predominantly originated from the hemicellulose fraction of lignocellulosic substrates [23]. The dilute acid pretreatment and $\mathrm{FeCl}_{3}$ pretreatment can markedly solubilize hemicellulose into monomeric sugars and soluble oligomers $[23,27]$. Results in Table 1 indicate that DALP significantly removed both lignin and hemicellulose, while DAP and FCP preferentially removed hemicellulose. Samples pretreated by DALP had the lowest lignin content of $11.7 \%$. A similar delignification effect was also observed in alkaline pretreatment and microwave-assisted alkaline pretreatment processes for different stalk wastes $[6,15,30,31]$.

\subsection{Effect of Different Pretreatments on Cell Structure}

Cell structure changes of the stalk samples pretreated by DAP, DALP and FCP were also studied by a scanning electron microscopy $(\mathrm{SEM})$ at the same magnification $(\times 500)$ (Figure 1$)$.

As shown in Figure 1a, the untreated P. alopecuroides sample had a smooth and intact surface with an unchanged fibrous structure organization. On the other hand, the cell walls of the DAP sample were obviously destroyed. It can be seen in Figure $1 \mathrm{~b}$ that the rectangular cell wall boundaries became blurry to some extent, indicating that a portion of cellulosic components could have been removed by DAP. The cell surfaces of the FCP sample were also not smooth, and partly broken (Figure 1d). This clearly verifies that the removal of lignocellulosic components such as hemicellulose by FCP resulted in morphological surface modification. Stronger morphological changes were observed from the DALP sample. As can be seen in Figure 1c, the surfaces and cell walls of the DALP sample were significantly destroyed and distorted. Enhanced destruction of plant cell wall was also found in previous studies with microwave-assisted acid/alkaline pretreatments of lignocellulosic wastes [22,23,32]. The present study suggests that the strong delignification effect and partial removal of hemicellulose by DALP remarkably enhances the destruction effect to cell wall structure (Table 1 and Figure 1). The formation 
of cracks, fragments and the distortion of cell structure induced by DALP could lead to the formation of many reactive sites on the biomass surface. Such changes increasingly benefit the accessibility of stalk samples to enzymes and bacteria, and consequently accelerate the subsequent bioconversion process.

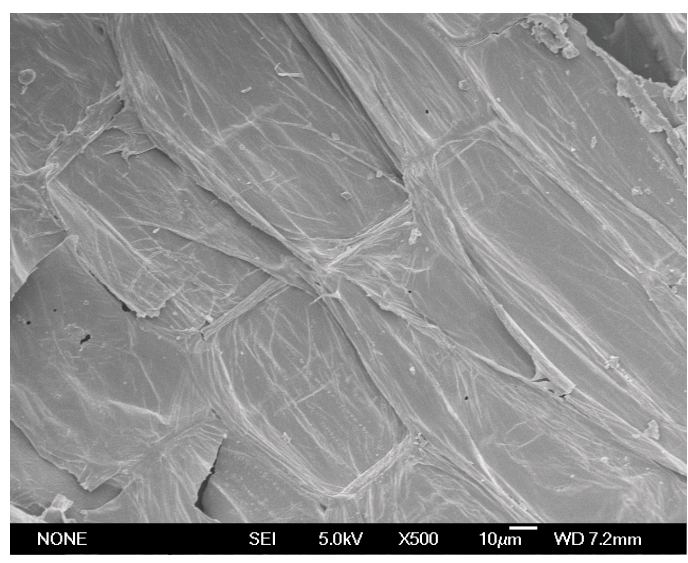

(a) Untreated sample

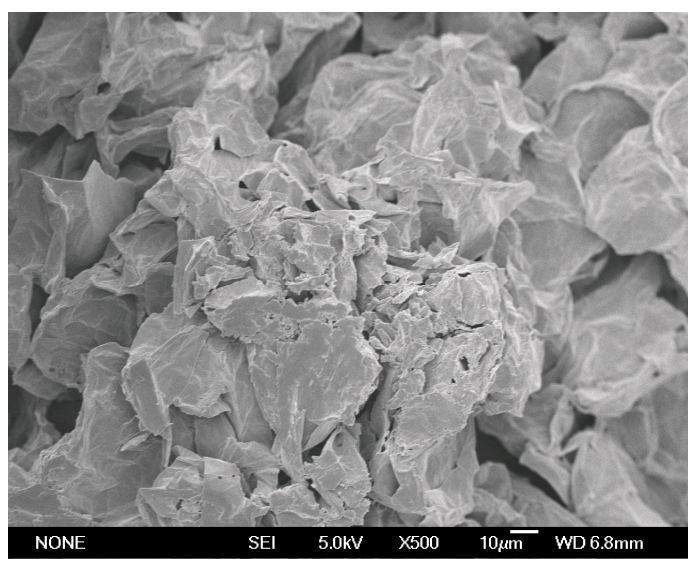

(c) DALP sample

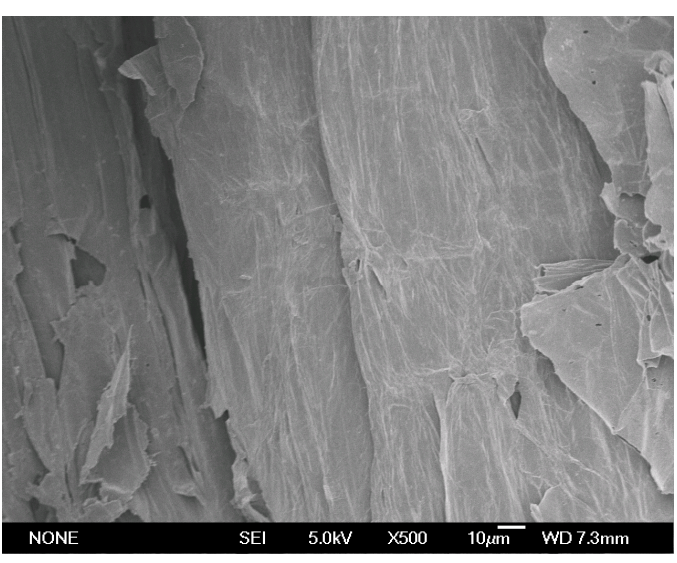

(b) DAP sample

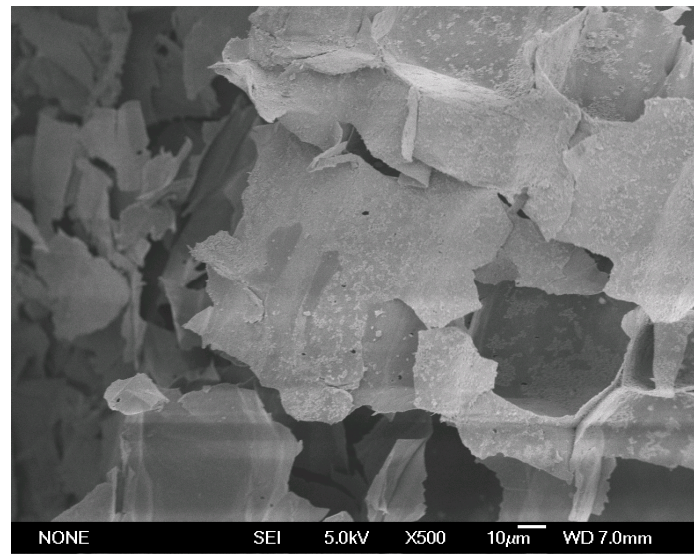

(d) FCP sample

Figure 1. SEM images of $P$. alopecuroides samples with and without pretreatments (500x): (a) untreated sample; (b) sample with DAP; (c) sample with DALP; (d) sample with FCP.

\subsection{Effect of Different Pretreatments on Enzymatic Hydrolysis}

Enzymatic hydrolysis was carried out to evaluate the enhancement of biodegradability of P. alopecuroides biomass pretreated with DAP, DALP and FCP. As shown in Figure 2, the untreated sample displayed its lowest reducing sugar yield after $72 \mathrm{~h}$ of enzymatic hydrolysis $(134.8 \mathrm{mg} / \mathrm{g}$ raw stalk). Meanwhile, samples pretreated with $3.0 \% \mathrm{H}_{2} \mathrm{SO}_{4}$ solution and $3.2 \% \mathrm{FeCl}_{3}$ solution under $121{ }^{\circ} \mathrm{C}$ for $30 \mathrm{~min}$ exhibited varied increases in enzymatic hydrolysis efficiency. The reduced sugar yields of the pretreated samples by DAP and FCP reached $258.3 \mathrm{mg} / \mathrm{g}$ pretreated stalk (PS) and $293.7 \mathrm{mg} / \mathrm{g}$ PS, increasing by $92 \%$ and $118 \%$ as compared with the untreated samples, respectively. DALP appeared to be the most efficient pretreatment technique by which to obtain the highest reducing sugar yield among all tested pretreatment methods (669.7 mg/g PS) (Figure 2). 


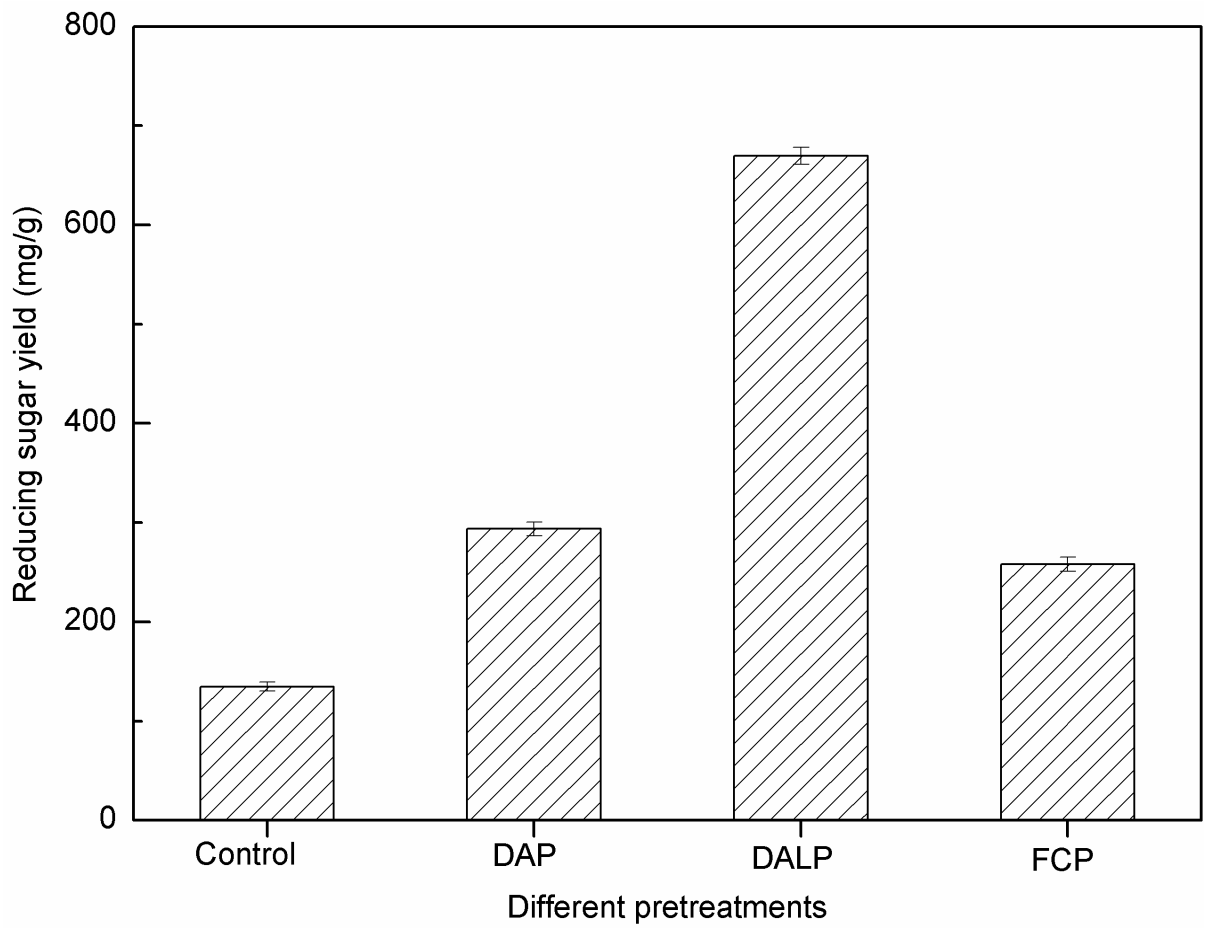

Figure 2. Effect of DAP, DALP and FCP on enzymatic hydrolysis.

The highly ordered crystalline structure of cellulose fibrils, the presence of lignin polymer and the recalcitrant cellulose-hemicellulose-lignin network structure in lignocellulosic biomass severely hindered enzymatic hydrolysis [33,34]. As shown in Table 1 and Figure 1, decreases in hemicellulose content and changes in cell structure, emerging after acid pretreatments (especially FCP), were responsible for the significant increase in reducing sugar yield. It is obvious that the pretreated sample by DALP, in which much more lignin components were removed, showed a much higher reducing sugar yield than those of DAP and FCP samples. The connection between these results strengthens a hypothesis that lignin removal is relatively important for improving enzymatic hydrolysis. This is because delignification not only reduces the adsorption of cellulase onto lignin, but also produces higher cellulose substrate content, consequently making cellulose more accessible to enzymes [30,31,33,34]. A stronger destruction of cell wall and higher increase of cellulose accessibility in DALP samples also produced a positive impact on enzymatic hydrolysis, affirmed by SEM observation (Figure 1).

\subsection{Effect of $\mathrm{H}_{2} \mathrm{SO}_{4} / \mathrm{NaOH} / \mathrm{FeCl} \mathrm{Cl}_{3}$ Concentrations on Biomass Composition}

The effects of $\mathrm{H}_{2} \mathrm{SO}_{4} / \mathrm{NaOH} / \mathrm{FeCl}_{3}$ concentrations in different pretreatment processes on the chemical characteristics of pretreated samples were further studied. The corresponding acid, alkali and $\mathrm{FeCl}_{3}$ concentrations in DAP, DALP and FCP were selected based on previous studies $[7,22,23,27]$. In DAP, as the $\mathrm{H}_{2} \mathrm{SO}_{4}$ concentrations increased from $1.0 \%$ to $4.0 \%$, the solid yields decreased from $59.4 \%$ to $52.6 \%$. The reduction in solids was mainly ascribed to the degradation of lignocellulosic components. As can be seen in Table 2, the corresponding hemicellulose contents decreased from $16.9 \%$ to $12.2 \%$, consistent with the decrease of solid yields. Removed cellulosic components were partially converted into soluble sugars, and the corresponding sugar concentrations in the aqueous phase significantly increased from $40.0 \mathrm{mg} / \mathrm{g}$ RS to $119.3 \mathrm{mg} / \mathrm{g}$ RS (Table 2). Due to the removal of hemicellulose, cellulose contents increased. 
Table 2. The effects of $\mathrm{H}_{2} \mathrm{SO}_{4} / \mathrm{NaOH} / \mathrm{FeCl}_{3}$ concentrations during pretreatments of $P$. alopecuroides on its chemical composition.

\begin{tabular}{ccccccc}
\hline $\begin{array}{c}\text { Different } \\
\text { Pretreatment }\end{array}$ & $\begin{array}{c}\mathbf{H}_{\mathbf{2}} \mathbf{S O}_{4} / \mathbf{N a O H} / \mathrm{FeCl}_{3} \\
\text { Concentrations (\%) }\end{array}$ & $\begin{array}{c}\text { Solid Yield } \\
\text { (\%) }\end{array}$ & $\begin{array}{c}\text { Hemicellulose } \\
\text { Content (\%) }\end{array}$ & $\begin{array}{c}\text { Cellulose } \\
\text { Content (\%) }\end{array}$ & $\begin{array}{c}\text { Lignin } \\
\text { Content (\%) }\end{array}$ & $\begin{array}{c}\text { Soluble Sugar } \\
\text { from Pretreatment } \\
\text { (mg/g RS) }\end{array}$ \\
\hline Control & - & - & $28.7 \pm 0.4$ & $41.8 \pm 0.9$ & $17.5 \pm 0.6$ & $20.0 \pm 0.4$ \\
\hline DAP with $\mathrm{H}_{2} \mathrm{SO}_{4}$ & $1 \%$ & $59.4 \pm 1.0$ & $16.9 \pm 1.6$ & $51.8 \pm 1.9$ & $15.7 \pm 1.1$ & $40.0 \pm 1.3$ \\
& $2 \%$ & $55.0 \pm 0.9$ & $15.5 \pm 1.3$ & $55.0 \pm 0.5$ & $16.8 \pm 1.2$ & $69.5 \pm 1.2$ \\
& $3 \%$ & $53.3 \pm 1.7$ & $15.0 \pm 1.7$ & $55.9 \pm 2.3$ & $17.1 \pm 1.5$ & $112.2 \pm 2.0$ \\
& $4 \%$ & $52.6 \pm 2.1$ & $12.2 \pm 0.2$ & $56.5 \pm 1.6$ & $17.3 \pm 1.4$ & $119.3 \pm 0.7$ \\
\hline DALP with $\mathrm{NaOH}$ & $0.4 \%$ & $74.6 \pm 2.5$ & $22.0 \pm 0.9$ & $53.3 \pm 0.3$ & $14.5 \pm 0.4$ & $50.5 \pm 0.2$ \\
& $0.6 \%$ & $64.7 \pm 1.7$ & $17.4 \pm 0.9$ & $59.0 \pm 1.4$ & $14.0 \pm 0.1$ & $63.4 \pm 2.0$ \\
& $0.8 \%$ & $59.4 \pm 2.1$ & $16.0 \pm 0.2$ & $63.2 \pm 0.6$ & $12.6 \pm 0.1$ & $83.5 \pm 0.7$ \\
& $1.0 \%$ & $58.2 \pm 1.2$ & $15.3 \pm 0.1$ & $64.1 \pm 1.7$ & $11.7 \pm 0.6$ & $86.7 \pm 0.2$ \\
& $1.2 \%$ & $53.9 \pm 1.7$ & $14.8 \pm 0.3$ & $68.0 \pm 0.7$ & $10.2 \pm 0.8$ & $107.3 \pm 0.6$ \\
\hline FCP with $\mathrm{FeCl}_{3}$ & $0.8 \%$ & $68.8 \pm 3.1$ & $15.2 \pm 1.7$ & $56.9 \pm 1.6$ & $18.0 \pm 1.6$ & $90.2 \pm 2.2$ \\
& $1.6 \%$ & $60.8 \pm 1.7$ & $13.5 \pm 1.5$ & $60.7 \pm 1.1$ & $17.3 \pm 0.1$ & $163.6 \pm 3.2$ \\
& $3.2 \%$ & $55.9 \pm 1.8$ & $11.9 \pm 1.3$ & $60.8 \pm 1.3$ & $16.4 \pm 0.7$ & $193.4 \pm 8.7$ \\
& $4.8 \%$ & $53.1 \pm 2.3$ & $9.7 \pm 1.7$ & $62.7 \pm 1.5$ & $15.3 \pm 1.5$ & $200.2 \pm 6.7$ \\
\hline
\end{tabular}

${ }^{1}$ The soluble sugar yield in the pretreatment process was calculated based on per g raw stalk (RS). Values are means of triplicate \pm standard deviation. RS: raw stalk.

In the case of FCP, severe pretreatment conditions $\left(3.2 \%\right.$ and $\left.4.8 \% \mathrm{FeCl}_{3}\right)$ also effectively removed cellulosic components, resulting in lower solid yields of $53.1 \sim 55.9 \%$ as compared with those of less severity conditions $\left(0.8 \sim 1.6 \% \mathrm{FeCl}_{3}\right)$ (Table 2). The significant decrease in hemicellulose content and the slight increase in cellulose content suggest that hemicellulose was more easily degraded than cellulose during FCP pretreatment $[7,18]$. The corresponding soluble sugar content in the aqueous phase also increased from $90.2 \mathrm{mg} / \mathrm{g}$ RS to $200.2 \mathrm{mg} / \mathrm{g}$ RS (Table 2). Due to the acidic condition provided by $\mathrm{H}_{2} \mathrm{SO}_{4}$ and $\mathrm{FeCl}_{3}$ during DAP and FCP, the generated soluble sugars could be dehydrated to furfural and 5-hydroxymethylfurfural (5-HMF) [23,27]. Although the solid yields obtained by DAP and FCP were similar, the soluble sugar concentrations in FCP samples were much higher than those observed in DAP samples (193.4 200.2 mg/g RS vs 112.2 119.3 mg/g RS), indicating that more generated soluble sugars may have been further converted into other byproducts by $\mathrm{H}_{2} \mathrm{SO}_{4}[23,27]$.

The mass loss observed after acid pretreatments can be mainly attributed to the removal of hemicellulose components [23,27]. Acid pretreatments such as DAP and FCP randomly break glycosidic bonds, removing hemicellulose while improving the cellulose content of lignocellulosic biomass and consequently increasing the accessibility of cellulose to hydrolytic enzymes [28,29]. On the other hand, alkaline pretreatments produce nucleophilic attacks that break the lignin structure, solubilizing lignin fragments or hemicellulose from $\alpha$-O-4 linkages [35-37]. Results in Table 2 show that relatively higher solid yields of $53.9 \sim 74.6 \%$ were observed in DALP samples. As the $\mathrm{NaOH}$ concentrations increased from $0.4 \%$ to $1.2 \%$, the hemicellulose contents decreased from $22.0 \%$ to $14.8 \%$, and cellulose contents significantly increased from $53.3 \%$ to $68.0 \%$. The corresponding soluble sugar concentrations also increased from $41.8 \mathrm{mg} / \mathrm{g}$ RS to $107.3 \mathrm{mg} / \mathrm{g}$ RS (Table 2). It should be noted that DALP, with 1.0 1.2\% NaOH, more significantly reduced the lignin contents of biomass to $10.2 \sim 11.7 \%$ as compared with those achieved by DAP and FCP (Table 2).

\subsection{Effect of $\mathrm{H}_{2} \mathrm{SO}_{4} / \mathrm{NaOH} / \mathrm{FeCl} \mathrm{Cl}_{3}$ Concentrations on Enzymatic Hydrolysis}

The effects of different $\mathrm{H}_{2} \mathrm{SO}_{4} / \mathrm{NaOH} / \mathrm{FeCl}_{3}$ concentrations on the enzymatic hydrolysis of P. alopecuroides biomass were also investigated. As shown in Figure 3, samples pretreated with DAP, DALP and FCP had much higher reducing sugar yields after enzyme hydrolysis, 1.4 5.5 times higher than that of the untreated sample $(134.8 \mathrm{mg} / \mathrm{g})$. In particular, the sample pretreated with $1.0 \% \mathrm{H}_{2} \mathrm{SO}_{4}$ solution under $121^{\circ} \mathrm{C}$ for 30 min exhibited an obvious increase in enzymatic hydrolysis efficiency, and the corresponding reducing sugar yield reached $258.1 \mathrm{mg} / \mathrm{g}$ PS. Increased acid concentrations showed a beneficial effect on cellulosic component removal and subsequent enzymatic hydrolysis. The reducing 
sugar yield reached a maximum value of $336.4 \mathrm{mg} / \mathrm{g}$ PS when P. alopecuroides biomass was pretreated with $4.0 \% \mathrm{H}_{2} \mathrm{SO}_{4}$. Similar improvements were observed during the FCP process. As can be seen in Figure 3, the reducing sugar yield of the sample pretreated with $0.8 \% \mathrm{FeCl}_{3}$ solution was $192.0 \mathrm{mg} / \mathrm{g}$ PS. The highest reducing sugar yield of $279.3 \mathrm{mg} / \mathrm{g}$ PS was obtained when $\mathrm{FeCl}_{3}$ concentration was increased to $4.8 \%$.

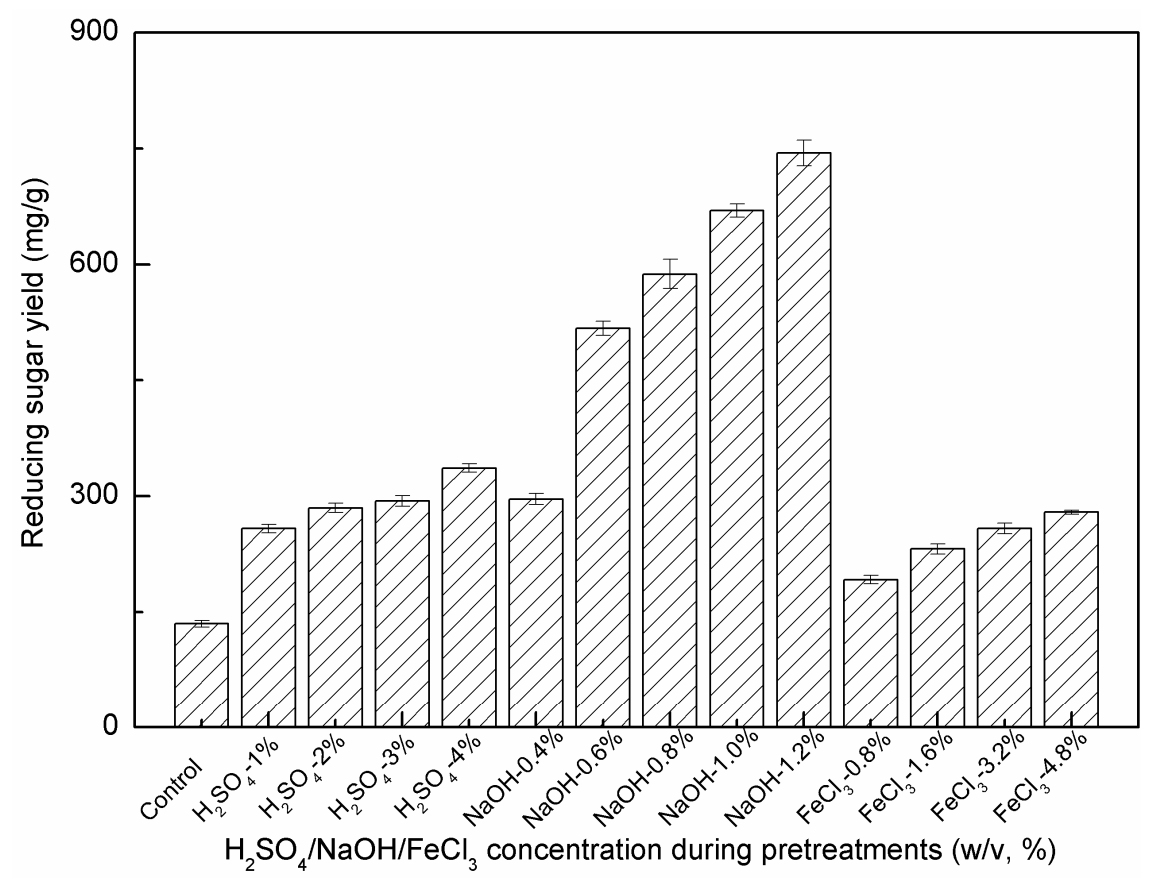

Figure 3. Effects of $\mathrm{H}_{2} \mathrm{SO}_{4} / \mathrm{NaOH} / \mathrm{FeCl}_{3}$ concentrations during pretreatments on enzymatic hydrolysis.

As can be seen in Figure 3, the enzymatic hydrolysis efficiency of DALP samples was the highest among the untreated sample and all pretreated samples. At the lowest $\mathrm{NaOH}$ concentration of $0.4 \%$, the reducing sugar yield of the DALP sample reached $296.1 \mathrm{mg} / \mathrm{g}$ PS, comparable to that obtained in samples pretreated with $3 \% \mathrm{H}_{2} \mathrm{SO}_{4}$ and $4.8 \% \mathrm{FeCl}_{3}$. DALP with higher $\mathrm{NaOH}$ concentrations $(0.6 \sim 1.2 \%)$ resulted in a significant improvement in hydrolysis performance. Compared to all tested samples, the highest reducing sugar yield was $744.4 \mathrm{mg} / \mathrm{g}$ PS using $1.2 \% \mathrm{NaOH}$. It should be also noted that some undesirable enzyme-inhibiting byproducts (mainly phenolic compounds, furans and organic acids) might be formed under certain pretreatment processes, especially those conducted at severe conditions (e.g., steam explosion, LHW, chemical treatments, $160 \sim 240{ }^{\circ} \mathrm{C}, 5 \sim 45 \mathrm{~min}$, pretreatment severity factor $\left(\log R_{0}\right)$ of 2.8 4.8) [11,38-40]. However, tested pretreatment strategies were still effective because cellulase was not inhibited in the subsequent enzymatic hydrolysis of the pretreated biomass, as illustrated by high reducing sugar yields of the pretreated samples (Figure 3). These results also confirmed the potential of these chemical pretreatment methods. The low inhibiting effect could be mainly attributed to the milder operation conditions (low acid/alkaline/ $\mathrm{FeCl}_{3}$ concentrations, $120{ }^{\circ} \mathrm{C}, 30 \mathrm{~min}$, pretreatment severity factor $\left(\log R_{0}\right)$ of 2.1$)$, which can lead to lower levels of byproducts $[11,20,41-43]$. In addition, most byproducts, such as the phenolics formed by the $\mathrm{NaOH}$ pretreatment, were retained in the pretreated liquors, resulting in a substantially lower level of phenolics in the enzyme-saccharified hydrolysates [44].

The effects of different pretreatment strategies on removing the physical barrier of lignin, reducing the dense crystalline structure and coating effect of hemicellulose and enhancing the accessibility of the pretreated biomass to hydrolytic enzymes were relatively complicated $[11,12,45,46]$. Results clearly indicate that both DAP and FCP were effective at removing hemicellulose components and destroying cell wall structure. The hemicellulose removal in DAP and FCP exhibited a positive relationship with the reducing sugar yields during the subsequent enzymatic hydrolysis (Table 2 and Figure 3). 
These results further support the observation that under acid/Lewis acid pretreatments, cellulose saccharification is linearly proportional to the amount of hemicellulose (mainly xylan) removed, since hemicellulose removal helps increase cellulose accessibility $[27,45]$. The reducing sugar yields (279.3 336.4 mg/g PS) and conversion ratios (34.6 44.5\%) by DAP and FCP were comparable to those observed in the pretreated bamboo $(77 \mathrm{mg} / \mathrm{g}$ PS), rice grass (457 $\mathrm{mg} / \mathrm{g}$ PS) and pine foliage (588 mg/g PS) pretreated with $1 \sim 2 \% \mathrm{H}_{2} \mathrm{SO}_{4}$ at $121^{\circ} \mathrm{C}$ for $60 \mathrm{~min}$ [19-21]. Notably, the simultaneous removals of lignin and hemicellulose were also positively related with the reducing sugar yields of the DALP samples (Table 2 and Figure 3). Despite lower hemicellulose removal, DALP provided a much higher delignification (Table 2) and reducing sugar recovery as compared with DAP and FCP (744.4 mg/g PS vs 279.3 336.4 mg/g PS, respectively). In addition to the obvious impact on delignification, significant enhancements on fermentable sugar releases were also observed in different biomass samples pretreated with $\mathrm{NaOH}$ under similar conditions, including bamboo, pine foliage, Pennisetum purpureum, wheat straw and Eucalyptus $(324 \sim 629 \mathrm{mg} / \mathrm{g}$ PS) $[17,20,34,44]$. These results indicate that effective lignin removal, as well as cellulose swelling induced by DALP, appeared to be more important factors in decreasing biomass recalcitrance and increasing enzymatic digestibility as compared with hemicellulose removal in DAP and FCP.

\subsection{Analysis of Mass Balance and Prospects for P. alopecuroides}

A promising pretreatment method not only enables the ability to obtain readily digestible substrates, but also maximizes the total yield of fermentable sugars. Table 3 shows the mass balance of stalk samples under different pretreatments and subsequent enzymatic hydrolysis. The highest reducing sugar yields in the aqueous phases under the optimal DAP, DALP and FCP conditions were $119.3 \mathrm{mg} / \mathrm{g}$ RS (DAP-4\% $\mathrm{H}_{2} \mathrm{SO}_{4}$ ), $107.3 \mathrm{mg} / \mathrm{g}$ RS (DALP-1.2\% NaOH) and $200.2 \mathrm{mg} / \mathrm{g}$ RS (FCP-4.8\% $\mathrm{FeCl}_{3}$ ). The solid yields under the above conditions were $52.6 \%, 53.9 \%$ and $53.1 \%$, respectively. The corresponding reducing sugar yields of enzymatic hydrolysis of the DAP, DALP and FCP samples were 336.4, 744.4 and $279.3 \mathrm{mg} / \mathrm{g}$ PS, respectively. Based the above data, the total soluble sugar yields from both pretreatment and enzymatic hydrolysis processes were 296.2, 508.5 and $348.6 \mathrm{mg} / \mathrm{g}$ RS, respectively. DAP had the lowest sugar recovery, partly because of its low enzymatic hydrolysis efficiency. Another reason was that cellulosic components, once removed, may be further converted into other byproducts, and thus the sugar yield from the aqueous phase during DAP was not high despite of its high weight loss. Among experimental conditions tested, DALP yielded the highest total sugar recovery through the whole process from pretreatment to enzymatic hydrolysis, while FCP indicated the most efficient method to recover soluble sugars only at pretreatment stage.

Table 3. Mass balance of the untreated and pretreated stalks.

\begin{tabular}{ccccc}
\hline $\begin{array}{c}\text { Different } \\
\text { Methods }\end{array}$ & $\begin{array}{c}\text { Solid } \\
\text { Yield (\%) }\end{array}$ & $\begin{array}{c}\text { Soluble Sugar } \\
\text { from Pretreatment } \\
\text { (mg/g RS) }\end{array}$ & $\begin{array}{c}\text { Soluble Sugar } \\
\text { from Enzymatic } \\
\text { Hydrolysis (mg/g PS) }\end{array}$ & $\begin{array}{c}\text { Soluble Sugar } \\
\text { from Enzymatic } \\
\text { Hydrolysis (mg/g RS) }\end{array}$ \\
\hline Control & - & - & - & $\begin{array}{c}\text { Total Soluble } \\
\text { Sugar Yield } \\
\text { (mg/g RS) }\end{array}$ \\
DAP & 52.6 & 119.3 & 336.4 & 134.8 \\
DALP & 53.9 & 107.3 & 744.4 & 176.9 \\
FCP & 53.1 & 200.2 & 279.3 & 401.2 \\
\hline
\end{tabular}

1 The total soluble sugar yield through the whole process from pretreatment to enzymatic hydrolysis was calculated based on per g raw stalk. RS: raw stalk; PS: pretreated stalk.

The fermentable sugar recovery from the $P$. alopecuroides sample pretreated by DALP was comparable to those obtained in the enzymatic hydrolysis of different lignocellulosic biomasses, as well as Pennisetum grass species [9,17,19,20,34,46,47]. As shown in Table 4, the maximum released sugar yields of $362.3 \sim 629 \mathrm{mg} / \mathrm{g}$ PS were obtained by acid or alkaline pretreatments of various biomass wastes such as wild rice grass, pine foliage, Eucalyptus and bamboo [19,20,34,46]. The optimal reducing sugar yield was only $146.9 \mathrm{mg} / \mathrm{g}$ pretreated elephant grass (P. purpureum) pretreated with $1.5 \% \mathrm{NaOH}$ at 
$121^{\circ} \mathrm{C}$ for $60 \mathrm{~min}$ [17]. Total fermentable sugar yields of $324 \sim 537 \mathrm{mg} / \mathrm{g}$ Napier grass (P. purpureum) were reported for samples pretreated with $2 \% \mathrm{Ca}(\mathrm{OH})_{2}$ or $2 \% \mathrm{NaOH}$ at $121{ }^{\circ} \mathrm{C}$ for $60 \mathrm{~min}$ [47]. In this study, the yield obtained so far on P. alopecuroides (pretreated with $1.2 \% \mathrm{NaOH}$ at $121^{\circ} \mathrm{C}$ for $30 \mathrm{~min}$ ) was $744.4 \mathrm{mg} / \mathrm{g}$ PS (508.5 mg/g RS, conversion ratio of $85.4 \%$ ), opening a potential avenue for efficient biofuel production from Pennisetum grass.

Table 4. Comparison of fermentable sugar recovery from different biomass.

\begin{tabular}{|c|c|c|c|c|}
\hline Biomass & Pretreatment Conditions & $\begin{array}{l}\text { Sugar Yield } \\
(\mathrm{mg} / \mathrm{g} \text { PS })^{1}\end{array}$ & $\begin{array}{l}\text { Conversion } \\
\text { Ratio }(\%)\end{array}$ & Ref. \\
\hline P. alopecuroides & $1.2 \% \mathrm{NaOH}, 121^{\circ} \mathrm{C}, 30 \mathrm{~min}$ & 744.4 & 85.4 & This study \\
\hline Wild rice grass & $2 \% \mathrm{H}_{2} \mathrm{SO}_{4}, 121^{\circ} \mathrm{C}, 60 \mathrm{~min}$ & 457 & 93.2 & [19] \\
\hline Bamboo & $1 \% \mathrm{NaOH}, 3 \%$ Tween $80,121^{\circ} \mathrm{C}, 60 \mathrm{~min}$ & 629 & 75.4 & [46] \\
\hline Bamboo & $1 \% \mathrm{H}_{2} \mathrm{SO}_{4}, 3 \%$ Tween $80,121^{\circ} \mathrm{C}, 60 \mathrm{~min}$ & 153 & 24.7 & [46] \\
\hline Pine foliage & $1 \% \mathrm{C}-\mathrm{TAB}, 1 \% \mathrm{H}_{2} \mathrm{SO}_{4}, 121^{\circ} \mathrm{C}, 60 \mathrm{~min}$ & 588 & 98.1 & [20] \\
\hline Pine foliage & $1 \%$ PEG-6000, $1 \% \mathrm{NaOH}, 121^{\circ} \mathrm{C}, 60 \mathrm{~min}$ & 477 & 88.4 & [20] \\
\hline Eucalyptus & $\begin{array}{l}12.5 \% \text { [TBA }][\mathrm{OH}] \text {, ultrasound irradiation } \\
\text { (at a power of } 360 \mathrm{~W} \text { for } 60 \mathrm{~min} \text { ) }\end{array}$ & 426.6 & 51.5 & [34] \\
\hline Eucalyptus & $\begin{array}{l}2 \% \mathrm{NaOH} \text {, ultrasound irradiation } \\
\text { (at a power of } 360 \mathrm{~W} \text { for } 60 \mathrm{~min} \text { ) }\end{array}$ & 362.3 & 56.6 & {$[34]$} \\
\hline P. purpureum Schum & $0.5 \% \mathrm{NaOH}, 90^{\circ} \mathrm{C}, 60 \mathrm{~min}$ & $\begin{array}{l}\text { (glucose yield: } \\
245 \mathrm{mg} / \mathrm{g} \text { RS) }\end{array}$ & NA & [9] \\
\hline P. purpureum & $1.5 \% \mathrm{NaOH}, 121^{\circ} \mathrm{C}, 60 \mathrm{~min}$ & 146.9 & 24.7 & [17] \\
\hline P. purpureum & $2 \% \mathrm{Ca}(\mathrm{OH})_{2}$ or $\mathrm{NaOH}, 121^{\circ} \mathrm{C}, 60 \mathrm{~min}$ & $324 \sim 537^{2}$ & $65.5 \sim 88.7$ & [47] \\
\hline
\end{tabular}

${ }^{1}$ Soluble sugar yields were calculated based on per g pretreated stalk. ${ }^{2}$ Sugar yields and conversion ratios were calculated on the basis of the reported data of the cellulose/hemecellulose contents and glucose/xylose/reducing sugar yields in the corresponding references. RS: raw stalk; PS: pretreated stalk; Ref.: references; NA: not available.

Results obtained in this study clearly illustrated that digestibility of P. alopecuroides biomass were significantly improved by DALP, hence this pretreated biomass could be used in bioethanol or biogas production [1,12-14]. In fact, the DALP sample could be directly fermented by mixed microorganisms for biogas production, hence omitting the enzymatic hydrolysis step using expensive cellulase [1,3-5]. The techno-economic feasibility of the DALP sample integrated with biogas production, in which energy recovery ranges from $50 \%$ to $85 \%$, has already been proven in several industrial biogas plants in China $[1,48,49]$.

The current pretreatment strategies can also be integrated with ethanol fermentation. An energy recovery of $37 \%$ was observed in full-scale ethanol production using starch substrates [49]. Lignocellulosic bioethanol production is also energetically sustainable based on heat/electricity production from fermentation residues, while greenhouse gas (GHG) emissions are decreased by $50 \sim 93 \%$ in this process [50]. It should be noted that the industrial application of lignocellulosic bioethanol production was still limited to some extent due to the high cost of cellulase (about USD 0.50 per gallon ethanol, accounting for $20 \%-30 \%$ of total costs [51]). However, recent techno-economic analysis indicated that the evaluated minimum ethanol selling price (MESP) decreased from USD 4.58 per gallon to USD 1.91 2.46 per gallon, which comes close to the market price of ethanol (USD 2.50 3.10 per gallon) [52-55]. Additionally, many studies have also been conducted to further resolve the bottleneck of enzymatic hydrolysis in lignocellulosic bioethanol production as follows: 1) improving production/activity of cellulase using mutagenesis, co-culturing and heterologous gene expression of cellulases; 2) reusing enzymes by immobilization; and 3) process optimization and integration (e.g., simultaneous saccharification and fermentation processes, cost-effective pretreatment, etc.) for reducing the cost [12-14]. These research avenues are undoubtedly making lignocellulosic bioethanol more economically viable.

It should be noted that due to limited farmland resources in China, planting energy crops on available marginal land, which is estimated to be about 5.5 million ha, is regarded as one of the most promising choices for the production of biofuel feedstocks [56]. If $20 \%$ of the marginal land area is used for planting P. alopecuroides and the dry biomass yield is about $30 \mathrm{t} / \mathrm{ha}$, theoretically about eight million tons of cellulosic ethanol can be produced annually, assuming a $12 \%$ biomass moisture content 
and an ethanol yield of $264 \mathrm{~kg} / \mathrm{t}$ of dry biomass [52]. This estimated potential yield would almost reach the 2020 ethanol target (10 million tons per year) in China.

\section{Materials and Methods}

\subsection{Materials}

Wild P. alopecuroides was manually collected from Fujian, China, and dried in the sun. After that, P. alopecuroides samples were dried in an oven at $60{ }^{\circ} \mathrm{C}$ for at least $24 \mathrm{~h}$ to a constant weight and then milled to pass through a 20-mesh sieve using a plant miller. The main composition of stalks (on a dry weight basis) was as follows: cellulose $41.8 \%$, hemicellulose $28.7 \%$ and lignin $17.5 \%$.

\subsection{Pretreatment Process}

Dried samples were added to glass bottles containing 1.0 4.0\% (w/v) sulfuric acid (DAP), $0.4 \sim 1.2 \%$ $(\mathrm{w} / \mathrm{v}) \mathrm{NaOH}(\mathrm{DALP})$ and $0.8 \sim 4.8 \%(\mathrm{w} / \mathrm{v}) \mathrm{FeCl}_{3}$ solutions (FCP), respectively, based on a solid loading rate of $10 \%[7,22,23,27]$. The above samples for all three pretreatments were then autoclaved at 121 ${ }^{\circ} \mathrm{C}$ for $30 \mathrm{~min}[7,22,23,27]$. After the pretreated samples were centrifuged, the supernatants were collected and stored at $-20^{\circ} \mathrm{C}$ for further analysis. The solid residues were washed with deionized water until the filtrates were neutral. The solids were then dried in an oven at $105^{\circ} \mathrm{C}$ to a constant weight. The dried solids were sealed in plastic bags and stored in a desiccator at room temperature until composition analysis and/or enzymatic hydrolysis.

\subsection{Enzymatic Hydrolysis}

The cellulase used for enzymatic hydrolysis were donated by Hunan Youtell Biochemical Co., Ltd. The protein content of the cellulase was $35 \mathrm{mg} / \mathrm{mL}$. The activities of cellulase, $\beta$-glucosidase and endoglucanase were $30 \mathrm{FPU} / \mathrm{mL}, 6.8 \mathrm{U} / \mathrm{mL}$ and $165 \mathrm{U} / \mathrm{mL}$, respectively. The enzymatic hydrolysis was performed in a $250-\mathrm{mL}$ conical flask using $50-\mathrm{mM}$ sodium acetate buffer ( $\mathrm{pH}$ 5) containing $40 \mu \mathrm{L}$ tetracycline hydrochloride with $2.5 \%$ solid loading at $50{ }^{\circ} \mathrm{C}$ and a 150 -rpm agitation rate for $72 \mathrm{~h}$. The enzyme was loaded at $15 \mathrm{FPU} / \mathrm{g}$ for the untreated and pretreated samples (i.e., $17.5 \mathrm{mg}$ enzyme protein/g solids). One unit of cellulase activity is defined as the amount of the enzyme that releases $1 \mu \mathrm{mol}$ of glucose per minute in the reaction mixture at $50^{\circ} \mathrm{C}$ and $\mathrm{pH} 5$. After solid-liquid separation via centrifugation, reducing sugars in the hydrolysate were analyzed by the 3, 5-dinitrosalicylic acid (DNS) assay [57]. All experiments were carried out in triplicate and all values were the means of triplicate \pm SD.

The biomass conversion to fermentable sugar was calculated using the equation [19,47]:

$$
\text { Conversion ratio }(\%)=100 \times \mathrm{Y}_{\mathrm{TRS}} /\left(1.111 \times \mathrm{C}_{\mathrm{C}}+1.136 \times \mathrm{C}_{\mathrm{HC}}\right)
$$

where $\mathrm{Y}_{\mathrm{TRS}}(\mathrm{g} / \mathrm{g}$ pretreated sample) is the total reducing sugar yield per gram of pretreated sample in the enzymatic hydrolysate; the constants 1.111 and 1.136 are the conversion factors for cellulose/hemicellulose to the equivalent reducing sugars; and $\mathrm{C}_{\mathrm{C}}$ and $\mathrm{C}_{\mathrm{HC}}$ (g/g pretreated sample) are the cellulose and hemicellulose contents per gram of pretreated sample.

\subsection{Scanning Electron Microscopy (SEM) Observation}

The stalk samples were used to observe cell destruction before and after different pretreatments via scanning electron microscopy (SEM). The dried samples were fixed on a specimen holder with aluminium tape, then sputtered with gold in a JEOL JEC-1200 sputter-coater (Tokyo, Japan). All specimens were examined with a JEOL JSM-5600 LV scanning electron microscope (Tokyo, Japan) under high vacuum and at an accelerating voltage of $5.0 \mathrm{kV}(10 \mu \mathrm{m}, 500 \times$ magnification). 


\subsection{Analytical Methods}

The sample mixtures were centrifuged and separated after pretreatments. The supernatants were collected to analyze total soluble sugar content. The solid residues were dried, and solid yields were recorded. Total solid and total soluble sugars were analyzed according to the standard methods [57-59]. The cellulose, hemicellulose and lignin contents were determined according to the standard method of Goering and Van-Soest [60], and calculated on the basis of residual total solids after pretreatments. All experiments were performed in triplicate, and all values were the means of triplicate \pm SD.

Pretreatment severity factor $\left(\log R_{0}\right)$ was calculated with the following equation [61,62]:

$$
R_{0}=\mathrm{t}^{*} \exp \left[\left(\mathrm{T}_{\mathrm{r}}-100\right) / 14.75\right]
$$

where $\mathrm{T}_{\mathrm{r}}$ is the reaction temperature $\left({ }^{\circ} \mathrm{C}\right), 100$ is the reference temperature $\left({ }^{\circ} \mathrm{C}\right)$ and $\mathrm{t}$ is the reaction time (min). The fitted value (14.75) is the arbitrary constant $\omega$.

\section{Conclusions}

Results in this study show that DAP, DALP and FCP resulted in the obvious structural changes and a high degree of hemicellulose and/or lignin removal from P. alopecuroides samples. Among all pretreatment methods tested, FCP produced the highest soluble sugar recovery $(200.2 \mathrm{mg} / \mathrm{g}$ raw stalk) at the pretreatment stage. In comparison with FCP and DAP, DALP offered a much higher delignification and stronger morphological changes, which could significantly enhance the accessibility of the pretreated stalks to the enzymes, and thereby improve the performance of enzymatic hydrolysis. DALP gave the highest total soluble sugar yield of the pretreatment enzymatic-hydrolysis process $(508.5 \mathrm{mg} / \mathrm{g}$ raw stalk). These results indicate that P. alopecuroides, a popular grass in huge quantities in China, could be used as a promising feedstock for biofuel production.

Author Contributions: Conceptualization, S.T. and C.X.; methodology, S.T., C.X., S.L. and L.L.; software, P.Y.; validation, M.C., S.L. and Y.W. (Yue Wu); formal analysis, C.X., Y.W. (Yining Wang) and X.X.; investigation, C.X., S.T., S.L., Y.W. (Yuxuan Wu), Y.X. and Q.Y.; resources, C.X., Q.Y. and X.C.; data curation, S.T.; writing-original draft preparation, S.T. and X.C.; writing-review and editing, X.C., L.V., and Q.Y.; supervision, X.C.; project administration, X.C.; funding acquisition, X.C.

Funding: This study was financially funded by Fundamental Research Funds for the Central Universities (grant number 2017JBM073), Beijing Jiaotong University Training Program of Research for Undergraduates (grant number 180170142), the Open Research Fund Program of Key Laboratory of Cleaner Production and Integrated Resource Utilization of China National Light Industry (grant number CP-2019-YB6) and the National Natural Science Foundation of China (No. 21306009).

Conflicts of Interest: The authors declare no conflict of interest.

\section{References}

1. Caruso, M.C.; Braghieri, A.; Capece, A.; Napolitano, F.; Romano, P.; Galgano, F.; Altieri, G.; Genovese, F. Recent updates on the use of agro-food waste for biogas production. Appl. Sci. 2019, 9, 1217. [CrossRef]

2. You, Z.; Zhang, S.; Kim, H.; Chiang, P.C.; Sun, Y.; Guo, Z.; Xu, H. Effects of corn stover pretreated with NaOH and $\mathrm{CaO}$ on anaerobic co-digestion of swine manure and corn stover. Appl. Sci. 2019, 9, 123. [CrossRef]

3. Cheng, X.Y.; Zhong, C. Effects of feed to inoculum ratio, co-digestion and pretreatment on biogas production from anaerobic digestion of cotton stalk. Energy Fuels 2014, 28, 3157-3166. [CrossRef]

4. Cheng, X.Y.; Liu, C.Z. Enhanced coproduction of hydrogen and methane from cornstalks by a three-stage anaerobic fermentation process integrated with alkaline hydrolysis. Bioresour. Technol. 2012, 104, 373-379. [CrossRef]

5. Cheng, X.Y.; Li, Q.; Liu, C.Z. Coproduction of hydrogen and methane via anaerobic fermentation of cornstalk waste in continuous stirred tank reactor integrated with up-flow anaerobic sludge bed. Bioresour. Technol. 2012, 114, 327-333. [CrossRef] [PubMed] 
6. Kang, X.H.; Sun, Y.M.; Li, L.H.; Kong, X.Y.; Yuan, Z.H. Improving methane production from anaerobic digestion of Pennisetum Hybrid by alkaline pretreatment. Bioresour. Technol. 2018, 255, 205-212. [CrossRef] [PubMed]

7. Camesasca, L.; Ramı'rez, M.B.; Guigou, M.; Ferrari, M.D.; Lareo, C. Evaluation of dilute acid and alkaline pretreatments, enzymatic hydrolysis and fermentation of napiergrass for fuel ethanol production. Biomass Bioenergy 2015, 74, 193-201. [CrossRef]

8. Wang, S.D.; Chen, J.H.; Yang, G.H.; Gao, W.H.; Chen, K.F. Efficient conversion of Hybrid Pennisetum to glucose by oxygen-aqueous alkaline ionic liquid media pretreatment under benign conditions. Bioresour. Technol. 2017, 243, 335-338. [CrossRef]

9. Tsai, M.H.; Lee, W.C.; Kuan, W.C.; Sirisansaneeyakul, S.; Savarajara, A. Evaluation of different pretreatments of Napier grass for enzymatic saccharification and ethanol production. Energy Sci. Eng. 2018, 6, 683-692. [CrossRef]

10. Scordia, D.; Cosentino, S.L.; Jeffries, T.W. Effectiveness of dilute oxalic acid pretreatment of Miscanthus $\times$ giganteus biomass for ethanol production. Biomass Bioenergy 2013, 59, 540-548. [CrossRef]

11. Kim, D. Physico-chemical conversion of lignocellulose: Inhibitor effects and detoxification strategies: A mini review. Molecules 2018, 23, 309. [CrossRef]

12. Kumari, D.; Singh, R. Pretreatment of lignocellulosic wastes for biofuel production: A critical review. Renew. Sustain. Energy. Rev. 2018, 90, 877-891. [CrossRef]

13. Bensah, E.C.; Mensah, M. Chemical pretreatment methods for the production of cellulosic ethanol: Technologies and innovations. Int. J. Chem. Eng. 2013, 2013, 1-21. [CrossRef]

14. Latika, B.; Sonia, J.; Rumana, A. An economic and ecological perspective of ethanol production from renewable agro waste: A review. AMB Express 2012, 2, 65. [CrossRef]

15. Kucharska, K.; Rybarczyk, P.; Holowacz, I.; Lukajtis, R.; Glinka, M.; Kamiński, M. Pretreatment of lignocellulosic materials as substrates for fermentation processes. Molecules 2018, 23, 2937. [CrossRef]

16. Fu, S.F.; Chen, K.Q.; Zhu, R.; Sun, W.X.; Zou, H.; Guo, R.B. Improved anaerobic digestion performance of Miscanthus floridulus by different pretreatment methods and preliminary economic analysis. Energ. Convers. Manag. 2018, 159, 120-128. [CrossRef]

17. Eliana, C.; Jorge, R.; Juan, P.; Luis, R. Effects of the pretreatment method on enzymatic hydrolysis and ethanol fermentability of the cellulosic fraction from elephant grass. Fuel 2014, 118, 41-47. [CrossRef]

18. Sabanci, K.; Buyukkileci, A.Q. Comparison of liquid hot water, very dilute acid and alkali treatments for enhancing enzymatic digestibility of hazelnut tree pruning residues. Bioresour. Technol. 2018, 261, 158-165. [CrossRef]

19. Sahoo, D.; Ummalyma, S.B.; Okram, A.K.; Pandey, A.; Sankar, M.; Sukumaran, R.K. Effect of dilute acid pretreatment of wild rice grass (Zizania latifolia) from Loktak Lake for enzymatic hydrolysis. Bioresour. Technol. 2018, 253, 252-255. [CrossRef] [PubMed]

20. Pandey, A.K.; Negi, S. Impact of surfactant assisted acid and alkali pretreatment on lignocellulosic structure of pine foliage and optimization of its saccharification parameters using response surface methodology. Bioresour. Technol. 2015, 192, 115-125. [CrossRef] [PubMed]

21. Li, K.N.; Wan, J.M.; Wang, X.; Wang, J.F.; Zhang, J.H. Comparison of dilute acid and alkali pretreatments in production of fermentable sugars from bamboo: Effect of Tween 80. Ind. Crops Products 2016, 83, 414-422. [CrossRef]

22. Cheng, X.Y.; Liu, C.Z. Enhanced biogas production from herbal-extraction process residues by microwave-assisted alkaline pretreatment. J. Chem. Technol. Biotechnol. 2010, 85, 127-131. [CrossRef]

23. Liu, C.Z.; Cheng, X.Y. Improved hydrogen production via thermophilic fermentation of corn stover by microwave-assisted acid pretreatment. Int. J. Hydrogen Energy 2010, 35, 8945-8952. [CrossRef]

24. Menegol, D.; Schol, A.L.; Dillon, A.J.; Camassola, M. Influence of different chemical pretreatments of elephant grass (Pennisetum purpureum, Schum.) used as a substrate for cellulase and xylanase production in submerged cultivation. Bioprocess Biosyst. Eng. 2016, 39, 1455-1464. [CrossRef]

25. Kamireddy, S.R.; Li, J.B.; Tucker, M.; Degenstein, J.; Ji, Y. Effects and mechanism of metal chloride salts on pretreatment and enzymatic digestibility of corn stover. Ind. Eng. Chem. Res. 2013, 52, 1775-1782. [CrossRef]

26. Kang, K.E.; Park, D.H.; Jeong, G.T. Effects of inorganic salts on pretreatment of Miscanthus straw. Bioresour. Technol. 2013, 132, 160-165. [CrossRef] 
27. Zhang, H.D.; Lyu, G.J.; Zhang, A.P.; Li, X.; Xie, J. Effects of ferric chloride pretreatment and surfactants on the sugar production from sugarcane bagasse. Bioresour. Technol. 2018, 265, 93-101. [CrossRef]

28. Meng, X.; Foston, M.; Leisen, J.; Demartini, J.; Wyman, C.E.; Ragauskas, A.J. Determination of porosity of lignocellulosic biomass before and after pretreatment by using Simons'stain and NMR techniques. Bioresour. Technol. 2013, 144, 467-476. [CrossRef]

29. Brienzo, M.; Fikizolo, S.; Benjamin, Y.; Tyhoda, L.; Görgens, J. Influence of pretreatment severity on structural changes, lignin content and enzymatic hydrolysis of sugarcane bagasse samples. Renew. Energy 2017, 104, 271-280. [CrossRef]

30. Wang, W.H.; Zhang, C.Y.; Tong, S.S.; Cui, Z.Y.; Liu, P. Enhanced enzymatic hydrolysis and structural features of corn stover by $\mathrm{NaOH}$ and ozone combined pretreatment. Molecules 2018, 23, 1300. [CrossRef]

31. Li, H.; Chen, X.; Wang, C.; Sun, S.; Sun, R. Evaluation of the two-step treatment with ionic liquids and alkali for enhancing enzymatic hydrolysis of Eucalyptus: Chemical and anatomical changes. Biotechnol. Biofuels 2016, 9, 166. [CrossRef]

32. Yan, Y.H.; Zhang, C.H.; Lin, Q.X.; Wang, X.H.; Cheng, B.G.; Li, H.L.; Ren, J.L. Microwave-assisted oxalic acid pretreatment for the enhancing of enzyme hydrolysis in the production of xylose and arabinose from bagasse. Molecules 2018, 23, 862. [CrossRef]

33. Jin, S.; Zhang, G.; Zhang, P.; Li, F.; Wang, S.; Fan, S.; Zhou, S. Microwave assisted alkaline pretreatment to enhance enzymatic saccharification of catalpa sawdust. Bioresour. Technol. 2016, 221, 26-30. [CrossRef]

34. Wang, Z.N.; Hou, X.F.; Sun, J.; Li, M.; Chen, Z.Y.; Gao, Z.Z. Comparison of ultrasound-assisted ionic liquid and alkaline pretreatment of Eucalyptus for enhancing enzymatic saccharification. Bioresour. Technol. 2018, 254, 145-150. [CrossRef]

35. Shimizu, F.L.; Monteiro, P.Q.; Ghiraldi, P.H.C.; Melati, R.B.; Pagnocca, F.C.; Souza, W.; Sant'Anna, C.; Brienzo, M. Acid, alkali and peroxide pretreatments increase the cellulose accessibility and glucose yield of banana pseudostem. Ind. Crops Prod. 2018, 115, 62-68. [CrossRef]

36. Thomas, H.L.; Seira, J.; Escudi, R.; Carrère, H. Lime pretreatment of miscanthus: Impact on bmp and batch dry co-digestion with cattle manure. Molecules 2018, 23, 1608. [CrossRef]

37. Duque, A.; Manzanares, P.; González, A.; Ballesteros, M. Study of the application of alkaline extrusion to the pretreatment of Eucalyptus biomass as first step in a bioethanol production process. Energies 2018, 11, 2961. [CrossRef]

38. Ximenes, E.; Kim, Y.; Mosier, N.; Dien, B.; Ladisch, M. Deactivation of cellulases by phenols. Enzyme. Microb. Technol. 2011, 48, 54-60. [CrossRef]

39. Ximenes, E.; Kim, Y.; Mosier, N.; Dien, B.; Ladisch, M. Inhibition of cellulases by phenols. Enzyme. Microb. Technol. 2010, 46, 170-176. [CrossRef]

40. Michelin, M.; Ximenes, E.; de Lourdes Teixeira de Moraes Polizeli, M.; Ladisch, M.R. Effect of phenolic compounds from pretreated sugarcane bagasse on cellulolytic and hemicellulolytic activities. Bioresour. Technol. 2016, 199, 275-278. [CrossRef]

41. Monlau, F.; Sambusiti, C.; Barakat, A.; Quéméneur, M.; Trably, E.; Steyer, J.P.; Carrère, H. Do furanic and phenolic compounds of lignocellulosic and algae biomass hydrolyzate inhibit anaerobic mixed cultures: A comprehensive review. Biotechnol. Adv. 2014, 32, 934-951. [CrossRef]

42. Imman, S.; Arnthong, J.; Burapatana, V.; Champred, V.; Laosiripojana, N. Effects of acid and alkali promoters on compressed liquid hot water pretreatment of rice straw. Bioresour. Technol. 2014, 171, 29-36. [CrossRef]

43. Rivera, O.M.P.; Moldes, A.B.; Torrado, A.M.; Domínguez, J.M. Lactic acid and biosurfactants production from hydrolyzed distilled grape marc. Process Biochem. 2007, 42, 1010-1020. [CrossRef]

44. McIntosh, S.; Vancov, T. Optimisation of dilute alkaline pretreatment for enzymatic saccharification of wheat straw. Biomass Bioenergy 2011, 35, 3094-3103. [CrossRef]

45. Meng, X.Z.; Wells, T.; Sun, Q.N.; Huang, F.; Ragauskas, A. Insights into the effect of dilute acid, hot water or alkaline pretreatment on the cellulose accessible surface area and the overall porosity of Populus. Green Chem. 2015, 17, 4239-4246. [CrossRef]

46. Obeng, A.K.; Premjet, D.; Premjet, S. Fermentable sugar production from the peels of two durian (Durio zibethinus Murr.) cultivars by phosphoric acid pretreatment. Resources 2018, 7, 60. [CrossRef]

47. Phitsuwan, P.; Sakka, K.; Ratanakhanokchai, K. Structural changes and enzymatic response of Napier grass (Pennisetum purpureum) stem induced by alkaline pretreatment. Bioresour. Technol. 2016, 218, 247-256. [CrossRef] 
48. Jiao, X.X.; Jin, H.Y.; Wang, M.M. Research progress of straw pretreatment for anaerobic fermentation produc ing biogas in china. China Biogas 2011, 29, 29-39.

49. Yu, Y.; Zheng, P.; Chen, X.G.; Cai, J. Three typical fermentation utilization modes of biomass energy. Bull. Sci. Technol. 2009, 25, 854-859. (In Chinese) [CrossRef]

50. Moreno, J.; Dufour, J. Life cycle assessment of lignocellusosic bioethanol: Environmental impacts and energy balance. Renew. Sustain. Energy. Rev. 2015, 42, 1349-1361. [CrossRef]

51. Du, J. Novozymes accelerates cellulosic ethanol commercialized. China WTO Tribune 2010, 10, 81. (In Chinese) [CrossRef]

52. Duque, S.H.; Cardona, C.A.; Moncada, J. Techno-economic and environmental analysis of ethanol production from agroindustrial residues in Colombia. Energy Fuels 2015, 29, 775-783. [CrossRef]

53. Chovau, S.; Degrauwe, D.; Van der Bruggen, B. Critical analysis of techno-economic estimates for the production cost of lignocellulosic bio-ethanol. Renew. Sustain. Energy Rev. 2013, 26, 307-321. [CrossRef]

54. Gubicza, K.; Nieves, I.U.; Sagues, W.J.; Barta, Z.; Shanmugam, K.T.; Ingram, L.O. Techno-economic analysis of ethanol production from sugarcane bagasse using a liquefaction plus simultaneous saccharification and co-fermentation process. Bioresour. Technol. 2016, 208, 42-48. [CrossRef]

55. Denis, B.; Mark, M.W.; Robert, B. More than ethanol: A techno-economic analysis of a corn stover-ethanol biorefinery integrated with a hydrothermal liquefaction process to convert lignin into biochemicals. Biofuel. Bioprod. Bior. 2018, 12, 497-509. [CrossRef]

56. Chen, Y.Q.; Guo, X.D.; Liu, J.J.; Zhang, Z.J. Assessment of marginal land potential for energy plants in China. Land Develop. Eng. Res. 2017, 2, 1-7. (In Chinese)

57. Miller, G.L. Use of dinitrosalicylic acid reagent for determination of reducing sugar. Anal. Chem. 1959, 31, 426-428. [CrossRef]

58. State Environmental Protection Administration of China (SEPAC). The Methods for Water and Wastewater Monitoring and Analysis, 4th ed.; China Environmental Science Press: Beijing, China, 2002.

59. APHA. Standard Methods for the Examination of Water and Wastewater, 20th ed.; American Public Health Association: Washington, DC, USA, 1998.

60. Goering, H.K.; Van-Soest, P.J. Agricultural handbook No. 379. Forage fiber analyses, apparatus, reagents, procedures and some applications; U.S. Department of Agriculture: Washington, DC, USA, 1970.

61. Overend, R.P.; Chornet, E.; Gascoigne, J.A. Fractionation of lignocellulosics by steam-aqueous pretreatments [and discussion]. Philos. Trans. R. Soc. Lond. A 1987, 321, 523-536. [CrossRef]

62. Pedersen, M.; Meyer, A.S. Lignocellulose pretreatment severity-relating $\mathrm{pH}$ to biomatrix opening. New Biotechnol. 2010, 27, 739-750. [CrossRef]

Sample Availability: Samples of the chemical compounds used in this study are available from the authors.

(C) 2019 by the authors. Licensee MDPI, Basel, Switzerland. This article is an open access article distributed under the terms and conditions of the Creative Commons Attribution (CC BY) license (http://creativecommons.org/licenses/by/4.0/). 